\title{
GENOCÍDIO INDÍGENA
}

\section{INDIGENOUS GENOCIDE}

Cristóvão José dos Santos Júnior ${ }^{1}$

Povos originários desta terra

são perseguidos pela vil cobiça

da madeireira tétrica e insubmissa

que o sangue humano na carteira aferra...

Feridas pelo tiro que as desterra,

as tribos já vagueiam sem justiça,

aflitas pela moeda que enfeitiça

o coração grileiro desta guerra!

Sem lar, sem solo e sem qualquer família,

o corpo do índio canta sua vigília

e na sua Resistência encontra amparo.

Sua vida é demarcada para a morte

ao som da fúria de um esquema avaro

que enfrentamos com o peito grande e forte!

Submetido em: 19/03/2020

Aprovado em: 06/06/2020

${ }^{1}$ Doutor em Literatura e Cultura - UFBA. 